\title{
Promoter Hypermethylation of the RB1 Gene in Glioblastomas
}

\author{
Mitsutoshi Nakamura, Yasuhiro Yonekawa, Paul Kleihues, and Hiroko Ohgaki \\ International Agency for Research on Cancer (MN, PK, HO), Lyon, France; and Department of Neurosurgery (YY), \\ University Hospital, Zürich, Switzerland
}

SUMMARY: Loss of expression of the retinoblastoma gene (RB1) has been shown to occur in up to $25 \%$ of glioblastomas (WHO Grade IV). To elucidate the underlying mechanism, we assessed $R B 1$ promoter hypermethylation using methylation-specific polymerase chain reaction and $R B 1$ expression by immunohistochemistry in 35 primary (de novo) glioblastomas and in 21 secondary glioblastomas that had progressed from low-grade diffuse astrocytoma (WHO Grade II) or anaplastic astrocytoma (WHO Grade III). Promoter hypermethylation was significantly more frequent in secondary (9 of 21 , 43\%) than in primary glioblastomas (5 of $35,14 \% ; p=0.0258$ ). There was a clear correlation between loss of $R B 1$ expression and promoter hypermethylation. In the majority of glioblastomas with loss of $R B 1$ expression, there was promoter hypermethylation (11 of 13 , $85 \%$ ), whereas $93 \%$ of tumors with RB1 expression had a normal $R B 1$ gene status $(p<0.0001)$. In three glioblastomas, areas with and without $R B 1$ expression were microdissected; promoter hypermethylation was detected only in areas lacking RB1 expression. In patients with multiple biopsies, methylation of the $R B 1$ promoter was not detectable in the less malignant precursor lesions, ie, low-grade diffuse and anaplastic astrocytoma. These results indicate that promoter hypermethylation is a late event during astrocytoma progression and is the major mechanism underlying loss of RB1 expression in glioblastomas. (Lab Invest 2001, 81:77-82).

$G$ lioblastoma multiforme (WHO Grade IV) is the most frequent and malignant neoplasm of the human nervous system. The majority of glioblastomas develop rapidly in older patients (mean age, approximately 55 years) after a short clinical history and without clinical or histological evidence of a less malignant precursor lesion (primary or de novo glioblastoma). Secondary glioblastomas manifest in younger patients (mean age, approximately 40 years) through progression from low-grade diffuse astrocytoma (WHO Grade II) or anaplastic astrocytoma (WHO Grade III) (Kleihues and Ohgaki, 1999). Recent studies have shown that these glioblastoma subtypes develop through different genetic pathways (Biernat et al, 1997; Kleihues and Ohgaki, 1999; Lang et al, 1994; Tohma et al, 1998; von Deimling et al, 1992; Watanabe et al, 1996). Primary glioblastomas are characterized by EGFR amplification/overexpression, PTEN mutations, $p 16^{\mathrm{INK} 4 \mathrm{a}}$ homozygous deletion, and loss of heterozygosity (LOH) on chromosomes 10p and 10q (Biernat et al, 1997; Fujisawa et al, 2000; Kleihues and Ohgaki, 1999; Tohma et al, 1998; Watanabe et al, 1996), whereas secondary glioblastomas contain frequent $p 53$ mutations and show LOH preferentially on chromosomes 19q and 10q (Fujisawa et al, 2000;

Received September 12, 2000.

This study was supported by a grant from the Foundation for Promotion of Cancer Research, Japan.

Address reprint requests to: Dr. Hiroko Ohgaki, Unit of Molecular Pathology, International Agency for Research on Cancer, 69372 Lyon, France. E-mail:ohgaki@iarc.fr
Kleihues and Ohgaki, 1999; Nakamura et al, 2000b; Watanabe et al, 1996, 1997).

The retinoblastoma gene (RB1) at chromosome $13 q 14$ was originally identified as the gene responsible for the development of retinoblastomas (Lee et al, 1987). It functions as a negative regulator of cell proliferation at the G1/S checkpoint of the cell cycle by complexing with cellular proteins, such as the transcriptional factor E2F (Harbour and Dean, 2000; Weinberg, 1995). $\mathrm{LOH}$ at the RB1 locus has been found in $25-45 \%$ of glioblastomas (Burns et al, 1998; Henson et al, 1994; Ichimura et al, 1996; Nakamura et al, 2000b; Ueki et al, 1996); however, sequencing of all 27 exons of the $R B 1$ gene revealed inactivating mutations in only $5-12 \%$ of cases (Henson et al, 1994; Ichimura et al, 1996, 2000; Ueki et al, 1996), suggesting that other tumor suppressor gene(s) are present on chromosome 13q14. Like RB1 mutations in retinoblastomas (Hogg et al, 1993), most RB1 mutations in glioblastomas result in a truncated pRB protein (Henson et al, 1994; Ueki et al, 1996) that does not enter the nucleus. Homozygous deletions in the RB1 locus have been reported in a small fraction of glioblastomas (3 of 120,3\%) (Ichimura et al, 1996). Loss of RB1 expression was detected by immunohistochemistry in $5-27 \%$ of glioblastomas (Biernat et al, 1997; Burns et al, 1998; Henson et al, 1994; Nakamura et al, 1996; Ueki et al, 1996); however, there was no clear correlation between loss of RB1 expression and LOH at the RB1 locus (Burns et al, 1998; Henson et al, 1994; Ueki et al, 1996).

The objective of the present study was to assess $R B 1$ promoter hypermethylation in primary and sec- 
ondary glioblastomas as a potential underlying mechanism of loss of $R B 1$ expression. To assess the timing of these alterations during astrocytoma progression, we also analyzed less malignant precursor lesions, ie, low-grade diffuse astrocytomas and anaplastic astrocytomas, from the same patients.

\section{Results}

\section{RB1 Promoter Hypermethylation}

$R B 1$ promoter hypermethylation was detected in 14 of 56 (25\%) glioblastomas (Tables 1 and 2). Promoter methylation was significantly more frequent in secondary than in primary glioblastomas (14\% versus $43 \%, p=0.0258$, Tables 1 and 2).

$R B 1$ methylation was not detected in any of 15 low-grade diffuse astrocytomas or 10 anaplastic astrocytomas (Table 2). Methylated and unmethylated control DNAs showed the expected fragment size of 163 bp (Fig. 1).

\section{pRB Immunohistochemistry}

In 28 of 35 (80\%) primary and 15 of 21 (71\%) secondary glioblastomas, pRB immunoreactivity was detected, but the fraction of positive tumor cells varied considerably (Table 1). Six (17\%) primary and four (19\%) secondary glioblastomas showed loss of pRB expression throughout the section (Table 1).

\section{Correlation between RB1 Methylation and pRB Immunoreactivity}

Of 13 glioblastomas with loss of RB1 expression, 11 tumors (85\%) showed promoter hypermethylation, whereas 40 of $43(93 \%)$ cases with pRB immunoreactivity did not show RB1 methylation (Table 1, $p<$ 0.0001).

In three glioblastomas (Table 1, Cases 292, 59, and 70 ), most tumor areas showed $R B 1$ expression, but there were also focal areas with neoplastic cells that lacked RB1 expression (Fig. 2). In all three cases, promoter hypermethylation was detected only in areas lacking $\mathrm{pRB}$ immunoreactivity but not in the areas with $R B 1$ expression (Fig. 1, Table 1).

\section{Discussion}

The essential promoter region of $R B 1$ lies 185-206 bp upstream of the initiation codon and contains putative binding sites for the transcription factors RBF-1, Sp1, ATF, and E2F (Ohtani-Fujita et al, 1993). It contains $\mathrm{CpG}$ islands that are frequent sites of methylation (Ohtani-Fujita et al, 1993; Stirzaker et al, 1997). Hypermethylation in the $R B 1$ promoter region has been reported in $13 \%$ of unilateral retinoblastomas (Greger et al, 1994; Sakai et al, 1991) and $27 \%$ of pituitary adenomas (Simpson et al, 2000), suggesting that promoter hypermethylation is an alternative mechanism for mutational loss of RB1 expression.

In this study, one quarter of the glioblastomas showed promoter hypermethylation in the $R B 1$ gene.
RB1 methylation was detected more frequently in secondary than in primary glioblastomas. There was a clear correlation between loss of pRB expression detected by immunohistochemistry and promoter hypermethylation: the majority of glioblastomas with loss of $R B 1$ expression had RB1 promoter hypermethylation (11 of $13,85 \%)$, whereas the majority (93\%) of tumors with $R B 1$ expression had normal $R B 1$ gene status. These results indicate that promoter hypermethylation is the major mechanism underlying the loss of RB1 function in glioblastomas. This was supported by the finding that in three glioblastomas, promoter hypermethylation was detected only in areas lacking $\mathrm{pRB}$ immunoreactivity but not in the areas where $R B 1$ was expressed.

Loss of $R B 1$ expression has been found to correlate well with $\mathrm{LOH}$ at the $R B 1$ locus in hepatocellular carcinomas (Zhang et al, 1994), bladder carcinomas (Xu et al, 1993), and malignant neuroendocrine lung carcinomas (Gouyer et al, 1994). However, it did not correlate with $\mathrm{LOH}$ at the $R B 1$ locus in other tumors, including glioblastomas (Burns et al, 1998; Ueki et al, 1996), pituitary tumors (Pei et al, 1995; Simpson et al, 1999), and carcinomas of the breast (Borg et al, 1992), prostate (Cooney et al, 1996), ovary (Dodson et al, 1994; Kim et al, 1994), and head and neck (Yoo et al, 1994). Simpson et al (2000) recently showed that the majority of pituitary adenomas with loss of $R B 1$ expression without LOH on the RB1 locus had promoter hypermethylation. The present study confirms this mechanism and suggests that the lack of correlation between $R B 1$ expression and $\mathrm{LOH}$ on the $R B 1$ locus in glioblastomas frequently reflects promoter methylation as the underlying cause of loss of RB1 expression.

Hypermethylation has been considered one of the mechanisms of inactivation of the RB1 gene in the two-hit theory, because the majority of retinoblastomas with promoter hypermethylation showed LOH on the RB1 locus (Greger et al, 1994; Sakai et al, 1991). However, there is recent evidence that hypermethylation without $\mathrm{LOH}$ at this locus may be sufficient to cause loss of $R B 1$ expression. A majority of pituitary adenomas with hypermethylation showed loss of $R B 1$ expression without LOH at the RB1 locus (Simpson et al, 2000). We correlated RB1 expression with LOH on $R B 1$ locus in 24 previously published glioblastomas (Nakamura et al, 2000b). Six of nine (67\%) glioblastomas with hypermethylation showed loss of RB1 expression, and all of these retained heterozygosity on the $R B 1$ locus (data not shown).

Loss of $R B 1$ expression appears to be a prognostic factor in several human neoplasms, including glioblastomas. The mean survival of patients with glioblastomas showing $R B 1$ expression was 11 months, whereas for those lacking $R B 1$ expression it was 6 months (Nakamura et al, 1996). Similarly, the mean survival of patients with nonsmall cell lung carcinomas with loss or altered $R B 1$ expression was 18 months and therefore significantly shorter than that of patients with RB1 expression (32 months) (Xu et al, 1994). Kornblau et al (1998) reported that the level of expres- 
Table 1. pRB Expression and RB1 Promoter Hypermethylation in Glioblastomas

\begin{tabular}{|c|c|c|c|c|}
\hline Patient ID & Age/Sex & Location & $\mathrm{pRB} I \mathrm{HC} \mathrm{C}^{a}$ & $\begin{array}{c}R B 1 \text { promoter } \\
\text { hypermethylation }\end{array}$ \\
\hline \multicolumn{5}{|c|}{ Primary (de novo) glioblastoma } \\
\hline 93 & $65 / F$ & $\mathrm{~T}$ & + & - \\
\hline 94 & $50 / \mathrm{M}$ & $\mathrm{T}$ & +++ & - \\
\hline 95 & $58 / \mathrm{M}$ & 0 & +++ & - \\
\hline 96 & $61 / \mathrm{F}$ & TO & +++ & - \\
\hline 97 & $35 / F$ & $\mathrm{FT}$ & - & - \\
\hline 98 & $68 / F$ & $\mathrm{~F}$ & - & Methylation \\
\hline 99 & $34 / \mathrm{M}$ & $\mathrm{T}$ & - & - \\
\hline 101 & $46 / F$ & TO & ++ & - \\
\hline 103 & $48 / \mathrm{M}$ & $P$ & +++ & - \\
\hline 104 & $39 / F$ & $\mathrm{~T}$ & +++ & - \\
\hline 106 & $73 / \mathrm{M}$ & FT & + & - \\
\hline 107 & $51 / \mathrm{M}$ & FT & ++ & - \\
\hline 111 & $70 / F$ & FT & +++ & - \\
\hline 112 & $69 / F$ & TO & +++ & - \\
\hline 132 & $58 / \mathrm{M}$ & $\mathrm{FP}$ & ++ & - \\
\hline 133 & $55 / F$ & $\mathrm{~T}$ & +++ & - \\
\hline 134 & $58 / F$ & $\mathrm{~F}$ & + & - \\
\hline 135 & $63 / \mathrm{M}$ & $\mathrm{T}$ & + & - \\
\hline 136 & $63 / \mathrm{M}$ & $\mathrm{F}$ & +++ & - \\
\hline 138 & $63 / \mathrm{F}$ & $\mathrm{T}$ & - & Methylation \\
\hline 139 & $73 / \mathrm{M}$ & PO & ++ & - \\
\hline 140 & $47 / \mathrm{M}$ & $P$ & ++ & - \\
\hline 141 & $58 / F$ & TPO & +++ & - \\
\hline 233 & $59 / \mathrm{M}$ & $\mathrm{T}, \mathrm{BG}$ & +++ & - \\
\hline 256 & $56 / F$ & $\mathrm{~T}$ & ++ & - \\
\hline 257 & $50 / \mathrm{M}$ & $F, B G$ & +++ & - \\
\hline 258 & $65 / F$ & $\mathrm{~F}$ & +++ & - \\
\hline 288 & $69 / \mathrm{M}$ & $P$ & +++ & - \\
\hline 292 & $62 / \mathrm{M}$ & $P$ & $+++{ }^{b}$ & Methylation $^{c}$ \\
\hline 294 & $36 / \mathrm{M}$ & $P$ & +++ & - \\
\hline 296 & $63 / F$ & VE & - & Methylation \\
\hline 300 & $71 / F$ & TO & +++ & - \\
\hline 301 & $68 / F$ & $\mathrm{TP}$ & +++ & - \\
\hline 314 & $40 / \mathrm{M}$ & $\mathrm{F}$ & - & Methylation \\
\hline 344 & $47 / \mathrm{M}$ & $P$ & ++ & - \\
\hline \multicolumn{5}{|l|}{ Secondary glioblastoma } \\
\hline 11 & $33 / F$ & VE & + & - \\
\hline 25 & $44 / F$ & $\mathrm{~T}$ & + & Methylation \\
\hline 26 & $32 / F$ & $\mathrm{~F}$ & ++ & - \\
\hline 33 & $47 / \mathrm{M}$ & $\mathrm{F}$ & - & Methylation \\
\hline 35 & $53 / \mathrm{M}$ & $\mathrm{T}$ & ++ & - \\
\hline 51 & $40 / \mathrm{F}$ & $\mathrm{F}$ & ++ & - \\
\hline 57 & $26 / \mathrm{M}$ & $\mathrm{F}$ & ++ & - \\
\hline 58 & $33 / \mathrm{M}$ & FT & - & Methylation \\
\hline 59 & $40 / \mathrm{M}$ & FT & $+++{ }^{b}$ & Methylation $^{c}$ \\
\hline 60 & $31 / F$ & $\mathrm{~T}$ & +++ & - \\
\hline 65 & $46 / \mathrm{M}$ & $\mathrm{T}$ & + & - \\
\hline 68 & $52 / F$ & TPO & +++ & - \\
\hline 70 & $52 / \mathrm{M}$ & $\mathrm{PO}$ & $++^{b}$ & Methylation $^{c}$ \\
\hline 72 & $28 / F$ & $\mathrm{~F}$ & + & Methylation \\
\hline 85 & $41 / \mathrm{F}$ & TP & + & - \\
\hline 295 & $47 / \mathrm{M}$ & FT & - & Methylation \\
\hline 3 & $23 / F$ & $\mathrm{~T}$ & +++ & - \\
\hline 10 & $45 / F$ & $\mathrm{~T}$ & - & Methylation \\
\hline 13 & $30 / F$ & FP & + & Methylation \\
\hline 37 & $74 / \mathrm{M}$ & $\mathrm{T}$ & + & - \\
\hline 79 & $25 / F$ & TP & + & - \\
\hline
\end{tabular}

IHC, immunohistochemistry; F, frontal; T, temporal; P, parietal; 0, occipital; VE, paraventricle; BG, basal ganglia.

${ }^{a}$ The results of pRB immunohistochemistry were recorded as - , positive staining in $<5 \%$ of the tumor cells; + , positive staining in $5 \%-25 \%$ of the tumor cells; ++ , positive staining in $25 \%-50 \%$ of the tumor cells; and +++ , positive staining in $>50 \%$ of the tumor cells.

${ }^{b}$ Indicates the presence of areas with clusters of tumor cells lacking pRB expression.

${ }^{c}$ Methylation was detected in only the tumor areas lacking pRB expression. 
Table 2. Promoter Hypermethylation of the RB1 Gene in Astrocytic Brain Tumors

\begin{tabular}{|c|c|c|c|}
\hline & $\begin{array}{l}\text { WHO } \\
\text { grade }\end{array}$ & $\begin{array}{l}\text { No. of } \\
\text { cases }\end{array}$ & $\begin{array}{l}\text { No. of cases } \\
\text { with promoter } \\
\text { hypermethylation }\end{array}$ \\
\hline Primary glioblastoma & IV & 35 & $5(14 \%)$ \\
\hline Secondary glioblastoma & IV & 21 & $9(43 \%)^{*}$ \\
\hline Glioblastoma total & IV & 56 & $14(25 \%)$ \\
\hline Anaplastic astrocytoma & III & 10 & 0 \\
\hline $\begin{array}{l}\text { Low-grade diffuse } \\
\text { astrocytoma }\end{array}$ & II & 15 & 0 \\
\hline
\end{tabular}

* Significantly more frequent than in primary glioblastomas $(p=0.0258)$.

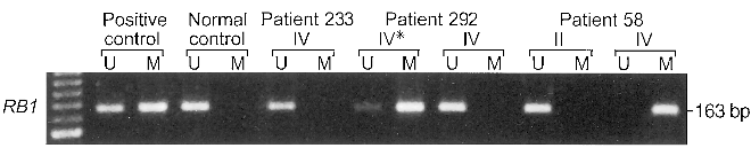

Figure 1.

Methylation-specific PCR of $\mathrm{CpG}$ islands of the RB1 promoter in low-grade diffuse astrocytomas (II) and glioblastomas (IV). In glioblastoma 233, only unmethylated DNA (U) was present. In glioblastoma 292, RB1 methylation (M) was restricted (asterisk) to areas lacking pRB immunoreactivity (Figure 2B). In Patient 58, the low-grade diffuse astrocytoma biopsy showed unmethylated status, whereas the glioblastoma derived from it contained a hypermethylated promoter region. Positive control for unmethylated and methylated DNA; normal control, DNA from a normal blood sample.

sion of pRB determined by immunohistochemistry was a strong prognostic factor in acute myelogenous leukemia, inferior survival rates being associated with no or low RB1 expression. In invasive transitional carcinomas of the bladder, loss of RB1 expression, together with p53 protein accumulation, was associated with significantly shorter survival (Cote et al, 1998). Non-small cell lung cancer with pRB-/p53+ also showed significantly shorter survival (5 year survival $20 \%$ ) in comparison with pRB +/p53- tumors (5 year survival 73\%) (Dosaka-Akita et al, 1997).

It has been reported that loss of $R B 1$ expression is associated with a higher grade of malignancy in several human neoplasms. The majority of parathyroid carcinomas (88\%) showed abnormal RB1 expression, whereas none of parathyroid adenomas analyzed had loss of RB1 expression (Cryns et al, 1994). A fraction of endometrial carcinomas lacked RB1 expression, whereas all hyperplastic lesions showed normal RB1 levels (Tsuda et al, 2000). In the present study, we observed RB1 promoter methylation only in glioblastomas and not in the less malignant precursor lesions, ie, low-grade diffuse and anaplastic astrocytoma, suggesting that loss of $R B 1$ expression is a late event during astrocytoma progression.

\section{Materials and Methods}

\section{Tumor Samples and DNA Extraction}

The surgical specimens of brain tumors were obtained from patients treated between 1977 and 1994 in the Department of Neurosurgery, University Hospital of Zürich, Switzerland. Tumors were fixed in buffered

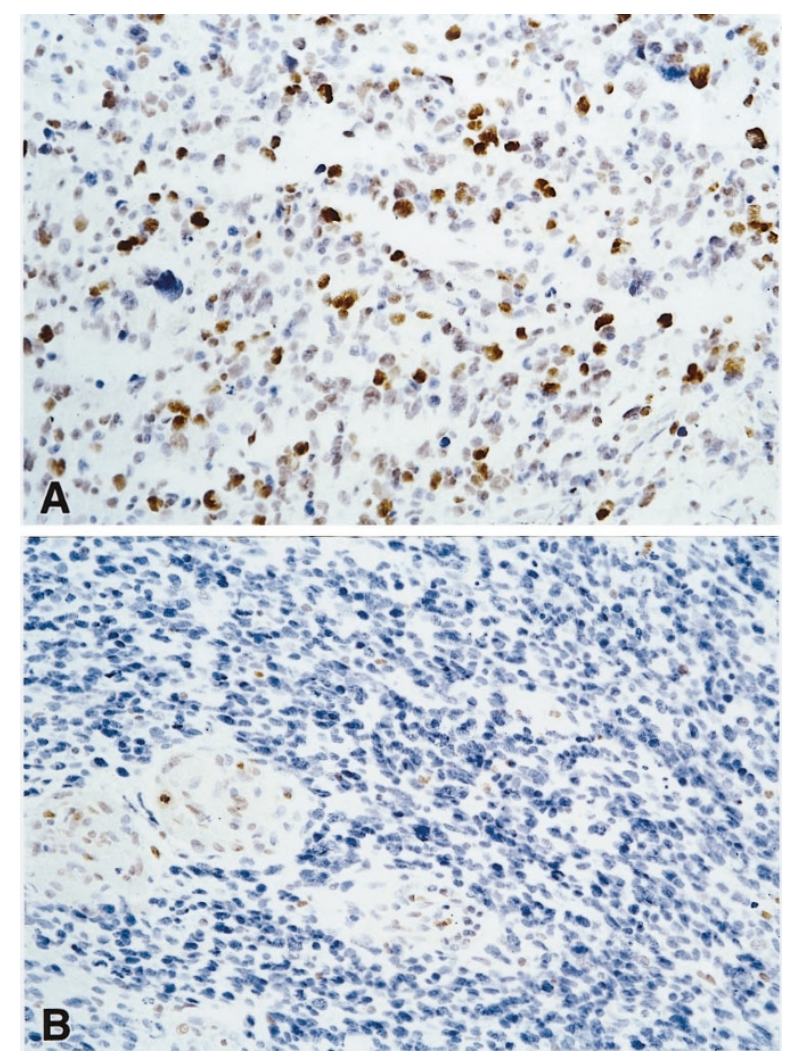

Figure 2.

A, pRB immunohistochemistry showing nuclear immunoreactivity in the majority of glioblastoma cells (Case 70). B, Loss of RB1 expression in clusters of undifferentiated neoplastic cells in a glioblastoma (Case 70), whereas vascular endothelial cells show RB1 expression. Magnification, $\times 155$.

formalin and embedded in paraffin. Pathological diagnosis was made according to the WHO classification (Kleihues and Cavenee, 2000). Thirty-five patients with primary glioblastoma had a preoperative clinical history of less than 3 months (mean, 1.5 months) and histologic diagnosis of a glioblastoma at the first biopsy, without any evidence of a less malignant precursor lesion. Twenty-one patients with secondary glioblastoma had at least 2 biopsies, with clinical and histologic evidence of progression from low-grade diffuse astrocytoma (16 cases, WHO Grade II) or anaplastic astrocytomas (5 cases, WHO Grade III). Low-grade diffuse astrocytomas (15 cases) and anaplastic astrocytomas (5 cases) from the same patients with secondary glioblastomas as well as five additional anaplastic astrocytomas were also examined. DNA was extracted from paraffin sections as described previously (Brüstle et al, 1992). In three glioblastomas (Cases 292, 59, and 70), pRB immunopositive or negative tumor areas were clearly recognized. These areas were carefully microdissected and analyzed separately.

\section{Methylation-Specific Polymerase Chain Reaction for RB1 Promoter Hypermethylation}

DNA methylation patterns in the CpG islands of the RB1 gene were determined by methylation-specific 
polymerase chain reaction (MSP) (Herman et al, 1996). Sodium bisulfite modification was performed using the CpGenome DNA Modification Kit (Intergen, Oxford, United Kingdom) as described previously (Nakamura et al, 2001). Primer sequences of $R B 1$ for the methylated and unmethylated reaction were as previously reported (Simpson et al, 2000). The PCR was carried out in a $10 \mu \mathrm{l}$ volume containing PCR buffer $(20 \mathrm{~mm}$ Tris pH 8.4, $50 \mathrm{~mm} \mathrm{KCl}$ ), $1.5 \mathrm{~mm} \mathrm{MgCl}_{2}$, dNTPs (250 $\mu \mathrm{m}$ each), primers (4 pmol each), 0.5 unit of PLATINUM Taq DNA polymerase (GIBCO BRL, Cergy Pontoise, France), and approximately $40 \mathrm{ng}$ bisulfite-modified DNA. Amplification was carried out in a DNA Thermal Cycler 480 (Perkin-Elmer Cetus, Norwalk, Connecticut) with initial denaturing at $95^{\circ} \mathrm{C}$ for 5 minutes followed by 35 cycles of denaturing at $95^{\circ} \mathrm{C}$ for 1 minute, annealing for 45 seconds at $65^{\circ} \mathrm{C}$ (for methylated $R B 1$ ) or $61^{\circ} \mathrm{C}$ (for unmethylated $R B 1$ ), extension for 1 minute at $72^{\circ} \mathrm{C}$, and then a final extension for 5 minutes at $72^{\circ} \mathrm{C}$. Amplified products were electrophoresed on a $3 \%$ agarose gel and were visualized with ethidium bromide.

\section{pRB Immunohistochemistry}

pRB immunohistochemistry was performed using the pRB monoclonal antibody (clone G3-245, which recognizes RB1 exons 9-12; PharMingen, San Diego, California) as previously described (Biernat et al, 1997) for Cases 233-344 and 295. The results of pRB immunohistochemistry in other cases were previously reported (Biernat et al, 1997). Fractions of positive cells were recorded as follows: positive in 5-25\% tumor cells $(+)$, positive in 25-50\% tumor cells $(++)$, or positive in $>50 \%$ tumor cells $(+++)$. pRB immunoreactivity in less than $5 \%$ of tumor cells or presence of clusters of tumor cells showing complete loss of $R B 1$ expression was regarded as negative (Biernat et al, 1997).

\section{References}

Biernat W, Tohma Y, Yonekawa Y, Kleihues P, and Ohgaki H (1997). Alterations of cell cycle regulatory genes in primary (de novo) and secondary glioblastomas. Acta Neuropathol 94:303-309.

Borg A, Zhang QX, Alm P, Olsson H, and Sellberg G (1992). The retinoblastoma gene in breast cancer: Allele loss is not correlated with loss of gene protein expression. Cancer Res 52:2991-2994.

Brüstle O, Ohgaki H, Schmitt HP, Walter GF, Ostertag H, and Kleihues P (1992). Primitive neuroectodermal tumors after prophylactic central nervous system irradiation in children. Association with an activated K-ras gene. Cancer 69:23852392.

Burns KL, Ueki K, Jhung SL, Koh J, and Louis DN (1998). Molecular genetic correlates of p16, cdk4, and pRb immunohistochemistry in glioblastomas. J Neuropathol Exp Neurol 57:122-130.

Cooney KA, Wetzel JC, Merajver SD, Macoska JA, Singleton TP, and Wojno KJ (1996). Distinct regions of allelic loss on $13 q$ in prostate cancer. Cancer Res 56:1142-1145.
Cote RJ, Dunn MD, Chatterjee SJ, Stein JP, Shi SR, Tran QC, Hu SX, Xu HJ, Groshen S, Taylor CR, Skinner DG, and Benedict WF (1998). Elevated and absent pRb expression is associated with bladder cancer progression and has cooperative effects with p53. Cancer Res 58:1090-1094.

Cryns VL, Thor A, Xu HJ, Hu SX, Wierman ME, Vickery AL, Jr, Benedict WF, and Arnold A (1994). Loss of the retinoblastoma tumor-suppressor gene in parathyroid carcinoma. N Engl J Med 330:757-761.

Dodson MK, Cliby WA, Xu HJ, DeLacey KA, Hu SX, Keeney GL, Li J, Podratz KC, Jenkins RB, and Benedict WF (1994). Evidence of functional RB protein in epithelial ovarian carcinomas despite loss of heterozygosity at the $R B$ locus. Cancer Res 54:610-613.

Dosaka-Akita H, Hu SX, Fujino M, Harada M, Kinoshita I, Xu HJ, Kuzumaki N, Kawakami Y, and Benedict WF (1997). Altered retinoblastoma protein expression in nonsmall cell lung cancer: Its synergistic effects with altered ras and p53 protein status on prognosis. Cancer 79:1329-1337.

Fujisawa H, Reis RM, Nakamura M, Colella S, Yonekawa $Y$, Kleihues $\mathrm{P}$, and Ohgaki $\mathrm{H}$ (2000). Loss of heterozygosity on chromosome 10 is more extensive in primary (de novo) than in secondary glioblastomas. Lab Invest 80:65-72.

Gouyer V, Gazzeri S, Brambilla E, Bolon I, Moro D, Perron P, Benabid AL, and Brambilla C (1994). Loss of heterozygosity at the $R B$ locus correlates with loss of RB protein in primary malignant neuro-endocrine lung carcinomas. Int $\mathrm{J}$ Cancer 58:818-824.

Greger V, Debus N, Lohmann D, Hopping W, Passarge E, and Horsthemke B (1994). Frequency and parental origin of hypermethylated RB1 alleles in retinoblastoma. Hum Genet 94:491-496.

Harbour JW and Dean DC (2000). Rb function in cell-cycle regulation and apoptosis. Nat Cell Biol 2:E65-E67.

Henson JW, Schnitker BL, Correa KM, von Deimling A, Fassbender F, Xu HJ, Benedict WF, Yandell DW, and Louis DN (1994). The retinoblastoma gene is involved in malignant progression of astrocytomas. Ann Neurol 36:714-721.

Herman JG, Graff JR, Myöhänen S, Nelkin BD, and Baylin SB (1996). Methylation-specific PCR: A novel PCR assay for methylation status of $\mathrm{CpG}$ islands. Proc Natl Acad Sci USA 93:9821-9826.

Hogg A, Bia B, Onadim Z, and Cowell JK (1993). Molecular mechanisms of oncogenic mutations in tumors from patients with bilateral and unilateral retinoblastoma. Proc Natl Acad Sci USA 90:7351-7355.

Ichimura K, Bolin MB, Goike HM, Schmidt EE, Moshref A, and Collins VP (2000). Deregulation of the p14 ${ }^{\mathrm{ARF}} / \mathrm{MDM} 2 / \mathrm{p} 53$ pathway is a prerequisite for human astrocytic gliomas with $\mathrm{G}_{1}-\mathrm{S}$ transition control gene abnormalities. Cancer Res 60: 417-424.

Ichimura K, Schmidt EE, Goike HM, and Collins VP (1996). Human glioblastomas with no alterations of the CDK2A (p16 ${ }^{\mathrm{INK} 4 \mathrm{~A}}, \mathrm{MTS} 1$ ) and CDK4 genes have frequent mutations of the retinoblastoma gene. Oncogene 13:1065-1072.

Kim TM, Benedict WF, Xu HJ, Hu SX, Gosewehr J, Velicescu M, Yin E, Zheng J, D'Ablaing G, and Dubeau L (1994). Loss of heterozygosity on chromosome 13 is common only in the biologically more aggressive subtypes of ovarian epithelial tumors and is associated with normal retinoblastoma gene expression. Cancer Res 54:605-609. 
Kleihues P and Cavenee WK, editors (2000). Pathology and genetics of tumours of the nervous system, 2nd ed. Lyon: International Agency for Research on Cancer Press.

Kleihues P and Ohgaki H (1999). Primary and secondary glioblastomas: From concept to clinical diagnosis. J NeuroOncol 1:44-51.

Kornblau SM, Andreeff M, Hu SX, Xu HJ, Patel S, Theriault A, Koller C, Kantarjian H, Estey E, Deisseroth AB, and Benedict WF (1998). Low and maximally phosphorylated levels of the retinoblastoma protein confer poor prognosis in newly diagnosed acute myelogenous leukemia: A prospective study. Clin Cancer Res 4:1955-1963.

Lang FF, Miller DC, Koslow M, and Newcomb EW (1994). Pathways leading to glioblastoma multiforme: A molecular analysis of genetic alterations in 65 astrocytic tumors. J Neurosurg 81:427-436.

Lee WH, Bookstein R, Hong F, Young LJ, Shew JY, and Lee EY (1987). Human retinoblastoma susceptibility gene: Cloning, identification, and sequence. Science 235:1394-1399.

Nakamura M, Konishi N, Hiasa Y, Tsunoda S, Fukushima Y, Tsuzuki T, Takemura K, Aoki H, Kobitsu K, and Sakaki T (1996). Immunohistochemical detection of CDKN2, retinoblastoma and p53 gene products in primary astrocytic tumors. Int J Oncol 8:889-893.

Nakamura M, Watanabe T, Klangby U, Asker C, Wiman K, Yasuhiro Y, Kleihues P, and Ohgaki H (2001). P14 Arf deletion and methylation in genetic pathways to glioblastomas. Brain Pathol 11:159-168.

Nakamura M, Yang F, Fujisawa $H$, Yonekawa $Y$, Kleihues $P$, and Ohgaki $\mathrm{H}$ (2000b). Loss of heterozygosity on chromosome 19 in secondary glioblastomas. J Neuropathol Exp Neurol 59:539-543.

Ohtani-Fujita N, Fujita T, Aoike A, Osifchin NE, Robbins PD, and Sakai T (1993). CpG methylation inactivates the promoter activity of the human retinoblastoma tumorsuppressor gene. Oncogene 8:1063-1067.

Pei L, Melmed S, Scheithauer B, Kovacs K, Benedict WF, and Prager D (1995). Frequent loss of heterozygosity at the retinoblastoma susceptibility gene $(R B)$ locus in aggressive pituitary tumors: Evidence for a chromosome 13 tumor suppressor gene other than RB. Cancer Res 55:1613-1616.

Sakai T, Toguchida J, Ohtani N, Yandell DW, Rapaport JM, and Dryja TP (1991). Allele-specific hypermethylation of the retinoblastoma tumor-suppressor gene. Am J Hum Genet 48:880-888.

Simpson DJ, Hibberts NA, McNicol AM, Clayton RN, and Farrell WE (2000). Loss of pRb expression in pituitary adenomas is associated with methylation of the RB1 CpG island. Cancer Res 60:1211-1216.

Simpson DJ, Magnay J, Bicknell JE, Barkan AL, McNicol AM, Clayton RN, and Farrell WE (1999). Chromosome 13q deletion mapping in pituitary tumors: Infrequent loss of the retinoblastoma susceptibility gene $(R B 1)$ locus despite loss of $R B 1$ protein product in somatotrophinomas. Cancer Res 59:1562-1566.
Stirzaker C, Millar DS, Paul CL, Warnecke PM, Harrison J, Vincent PC, Frommer M, and Clark SJ (1997). Extensive DNA methylation spanning the $R b$ promoter in retinoblastoma tumors. Cancer Res 57:2229-2237.

Tohma Y, Gratas C, Biernat W, Peraud A, Fukuda M, Yonekawa Y, Kleihues P, and Ohgaki H (1998). PTEN (MMAC1) mutations are frequent in primary glioblastomas (de novo) but not in secondary glioblastomas. J Neuropathol Exp Neurol 57:684-689.

Tsuda H, Yamamoto K, Inoue T, Uchiyama I, and Umesaki N (2000). The role of p16-cyclin D/CDK-pRb pathway in the tumorigenesis of endometrioid-type endometrial carcinoma. $\mathrm{Br} \mathrm{J}$ Cancer 82:675-682.

Ueki K, Ono Y, Henson JW, Efird JT, von Deimling A, and Louis DN (1996). CDKN2/p16 or RB alterations occur in the majority of glioblastomas and are inversely correlated. Cancer Res 56:150-153.

von Deimling A, von Ammon K, Schoenfeld DA, Wiestler OD, Seizinger BR, and Louis DN (1993). Subsets of glioblastoma multiforme defined by molecular genetic analysis. Brain Pathol 3:19-26.

Watanabe K, Sato K, Biernat W, Tachibana O, von Ammon K, Ogata N, Yonekawa Y, Kleihues P, and Ohgaki H (1997). Incidence and timing of p53 mutations during astrocytoma progression in patients with multiple biopsies. Clin Cancer Res 3:523-530.

Watanabe K, Tachibana O, Sato K, Yonekawa Y, Kleihues P, and Ohgaki H (1996). Overexpression of the EGF receptor and p53 mutations are mutually exclusive in the evolution of primary and secondary glioblastomas. Brain Pathol 6:217224.

Weinberg RA (1995). The retinoblastoma protein and cell cycle control. Cell 81:323-330.

Xu HJ, Cairns P, Hu SX, Knowles MA, and Benedict WF (1993). Loss of RB protein expression in primary bladder cancer correlates with loss of heterozygosity at the RB locus and tumor progression. Int $\mathrm{J}$ Cancer 53:781-784.

Xu HJ, Quinlan DC, Davidson AG, Hu SX, Summers CL, Li J, and Benedict WF (1994). Altered retinoblastoma protein expression and prognosis in early-stage non-small-cell lung carcinoma. J Natl Cancer Inst 86:695-699.

Yoo GH, Xu HJ, Brennan JA, Westra W, Hruban RH, Koch W, Benedict WF, and Sidransky D (1994). Infrequent inactivation of the retinoblastoma gene despite frequent loss of chromosome $13 q$ in head and neck squamous cell carcinoma. Cancer Res 54:4603-4606.

Zhang X, Xu HJ, Murakami Y, Sachse R, Yashima K, Hirohashi S, Hu SX, Benedict WF, and Sekiya T (1994). Deletions of chromosome 13q, mutations in Retinoblastoma 1, and retinoblastoma protein state in human hepatocellular carcinoma. Cancer Res 54:4177-4182. 